\section{JHASS 4,3}

\section{8}

Received 22 July 2020

Revised 30 November 2020 Accepted 13 December 2020

\section{Gender and rural economic relations: ethnography of the Nrobo of South Eastern Nigeria}

\author{
Ugochukwu Titus Ugwu \\ Department of Sociology/Anthropology, Faculty of Social Sciences, \\ Nnamdi Azikiwe University, Awka, Nigeria
}

\begin{abstract}
Purpose - The purpose of this study is to examine gender and rural economic relations of the Nrobo of Southeastern Nigeria. Specifically, the study was designed to examine the subsistence strategies, gendered role patterns and gender gaps in economic relations of the Nrobo.

Design/methodology/approach - This study used ethnographic methods of participant observation adopting chitchatting and semi-structured interviews. Also, focus group discussion (FGD) was used to crosscheck the validity of data from the other instrument.

Findings - This study found among other things, that although there is still verbal expression of gendered roles division, it does not mirror what actually obtains in society, except bio-social roles. Ideological superiority of men reflects the patrilineal kinship arrangement of society. Theoretically, some of the hypotheses of gender inequality theory were disputed for lack of adequate explanation of gender and economic relations in an egalitarian-reflected society such as Nrobo.

Originality/value - This study, to the best of my knowledge, is the first attempt to ethnographically examine gender and economic relations among this group. As such it adds to the corpus of ethnographies on the Igbo of Southeastern Nigeria.
\end{abstract}

Keywords Gender, Gender inequality, Ethnographic method, Gender and economic relations, Rural economic relations, Southeastern Nigeria, Gendered role patterns

Paper type Research paper

\title{
Introduction
}

Issues of gender inequality have been extensively explored in relation to contemporary Western and non-Western multicultural societies. The relationship between men and women in the economic nexus seems to impair women and subject them to little access to factors of production, which in turn limits women production potentials. For instance, the United Nations Development Programme (2018) sees gender inequality as one of the highest obstacles to human development. The implication is that the average human development

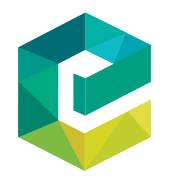

(C) Ugochukwu Titus Ugwu. Published in Journal of Humanities and Applied Social Sciences. Published by Emerald Publishing Limited. This article is published under the Creative Commons Attribution (CC BY 4.0) licence. Anyone may reproduce, distribute, translate and create derivative works of this article (for both commercial and non-commercial purposes), subject to full attribution to Journal of Humanities and Applied Social Sciences Vol. 4 No. 3, 2022 pp. 198-214 Ep. 198-214 2632-279X the original publication and authors. The full terms of this licence maybe seen at http:// creativecommons.org/licences/by/4.0/legalcode

The author's special appreciation goes to Professors P.-J. Ezeh and Au. N. Nnonyelu for their guidance throughout the study. Dr B.A. Mathias and Professor I.U. Nwankwo were instrumental to the completion of this study. 
index (HDI) for women is 6\% lower than that of men and as such, countries in the low development category suffer the widest gaps.

First is the gender development index (GDI), which reports female and male achievements in the basic dimensions of human development. Across the world, the average HDI value for women (0.705) is 5.9\% lower than that for men (0.749). Much of the gap is due to women's lower income and educational attainment in many countries. The gender gap is widest in low human development countries, where the average HDI value is $13.8 \%$ lower for women than for men (UNDP, 2018).

Gender relations, especially economic and political, among the Igbo of Nigeria attracted the attention of professional ethnographers following British colonization of Nigeria. LeithRoss (1965) narrates the equality of the sexes is so marked in "Ibo-land" [sic]. Lugard, the first colonial Governor-General of Nigeria, in a foreword to Leith-Ross's book stated that the power that women wielded in traditional Igbo society was remarkable. Leith-Ross actually expressed fear that the Igbo contact with the European practices through colonization and Christianity was bound to affect the autochthonous Igbo gender relations adversely. Amadiume (1997) suspects that the entire Igbo was once matriarchal at the level of power relations. McCall (2000) recalls that among the Ohafia, women wielded enormous economic power and can achieve whatever they want through hard work. Agbasiere (2001) also narrates how women are unavoidably present in Igbo life and thought. Furthermore, Equiano (1988) in a publication that was first made in 1789 recounts that those activities, especially economic and political, into which contemporary Western societies have begun admitting women were already open to Igbo women of his days.

Nsugbe (1974), states that Forde and Jones have described the Igbo as a single people, because of the broad similarities of their culture. However, he argues that to stress these cultural similarities might lead one to underestimate the differences, which a close study of the main groupings of the "Ibo" [sic] discloses. When therefore the "Ibo" is discussed, based on these groupings, such differences as those of dialect and social institutions become much more significant.

Floyd (1969), in his geographical review of Eastern Nigerian has identified Nrobo as a part of Nsukka culture division. However, the study did not explore gender and economic relations among the Nrobo. Considering the above, there seems to be a knowledge gap on gender and economic relations of the Nrobo. Furthermore, there has not been any attempt, to the best of my knowledge, to conduct a participant observation among this rural society, amid acculturation. Drawing from functionalism, this study sets to fill this gap by attempting to interrogate, ethnographically, gender and economic relationships among the Nrobo. Furthermore, it explores if subsistence strategies of the Nrobo-aided gender polarity or otherwise, especially with reality to earlier ethnographic studies among other Igbo groups. This study was designed to examine the subsistence strategies, gendered role patterns and gender gaps in the economic relations of the Nrobo.

I begin my discussion with an overview of relevant literature on gender and economic relations. I then look at the methods of data collection and analysis. Then I present and discuss the findings of this study. Finally, I examine the theoretical and practical implications of the findings.

\section{Literature review}

Cook (2007) notes that gender relations refer to complex, culturally and historically specific social systems that organize and regulate interactions between women and men, as well as their relative social value. Gender relations simultaneously encompass ideas, practices, representations and identities that pertain to gender. Because gender is often misunderstood 
$\underset{4,3}{\text { JHASS }}$

200

as being the study of women and femininity only, strictly, gender relations focus on the relationships between masculinity, the valuation of women and men and their relative access to, and control of resources.

As a social system, gender relations are a central organizing principle of society that govern, in part, processes of production, reproduction, consumption and the distribution of resources (Cook, 2007). Gender relations do not operate in isolation but are influenced and shaped by other systems that organize social interactions between groups of people, including the economy.

Michelle Rosaldo (as cited in Lamphere, 2007) states that although there is a great deal of cross-cultural variability in men and women's roles there is a pervasive, universal asymmetry between gender categories. She notes that the striking and surprising thing is the fact that male, as opposed to female activities are always recognized as predominantly important, and cultural systems give authority and value to the roles and activities of men. What needs to say here, however, is her generalization. This generalization is only a conjecture that may not be supported across cultures. The meanings these societies she selected attach to these gender roles need a careful and exhaustive investigation to unravel the emic connotation of such divisions.

Michelle Rosaldo (as cited in Lamphere, 2007) emphasizes that not only were there differential evaluations of women activities, but everywhere men have some authority over women. That they have culturally legitimated the right to women subordination and compliance.

Rosaldo's generalization may fail to the test generated by ethnographic evidence. For example, McCall (2000) demonstrates that Ohafia is a matrilineal society and women are in control. There may also be a society where the value of men is reduced to mere agents of impregnation. However, the case of absolute matriarchy may be found elsewhere. Even in some patriarchal societies, men are objects of ridicule (Green, 1964).

It is often claimed that women do most of the world's work and this may be true, but there is in fact little evidence for this claim (Baden and Goetz, 1998). The actual amount of work done overall, and the proportions carried out by men and women, respectively, may vary enormously (Benería, 1982). However, it is indisputable that the received models of thinking about work and material flows often obscured women's work and its importance.

There is a further issue here: what is named and counted as work within the society? Just as women's work inside the home was frequently uncounted as real work in Western capitalist systems, so what is counted locally as work may also intersect with indigenous gender categories to exclude certain kinds of activities (Narotzky, 1997). In most societies, a division of labour is legitimated and reinforced by ideological and cultural constructs, and gender divisions form a significant part of such divisions: sexual divisions of labour are frequently based on naturalized ideas of such work (Narotzky, 1997: 30). It is not surprising that unremunerated "women's work" in many societies, such as the work of caring for children, family members and housework, is not counted in contemporary national statistics.

These insights have been useful to archaeologists trying to reconstruct the history of economic activities in the widest sense. While extrapolating to the past is always problematic, the documentation of contemporary gatherers' and hunters' actual foodgathering practices suggested that the image of "man the hunter" (Lee and DeVore, 1968) both past and present, has been misleading. Women's gathering and trapping of small game, for example, has been shown to contribute significant number of calories in many gathering and hunting societies observed by anthropologists over the years (Sahlins, 1972; Harris, 1984; Hill and Hurtado, 1996; Lee, 2013). 
Several pioneering studies of women's economic activities have been particularly influential. The economist Boserup's (1989) Women's role in economic development, and anthropologist Goody's (1976) Production and reproduction, contrasted African and Asian systems of rural production to explore the links between the importance of women's labour for subsistence, technologies of production and property holding and types of marriage and kinship systems. Both ultimately saw the motors of change in technologies of production, rather than in relations of production. Boserup, very problematically, argued for integrating women into development, whereas her critics would respond that women were already fully integrated, but overlooked. Meillassoux's (1981) Maidens, meal and money concentrated on the relations of reproduction within what he calls the "domestic agricultural community." Drawing on West African examples where residence is with the husband (patrilocal, virilocal) and young men depend on their fathers for access to resources, he argued that such relations of reproduction play an important part in reproducing economic systems. He saw lineage elders' control of women's (and young men's) labour as key in reproducing society. Some anthropologists were enthusiastic about this, seeing it as a way to bring gender firmly into discussions of the development and reproduction of economic systems. Nevertheless, critics felt that he conflated biological and social reproduction, and ignored domestic labour (Edholm et al., 1977; Harris and Young, 1981; Moore, 1988). Ethnographic studies of the sexual division of labour have helped us see the wide variations in such divisions, and the ways in which a society may have an "official" version of its sexual division of labour, while in fact presenting different patterns in practice. Thus, in rural Malaysia, Stivens (1996) found that actual productive practices among smallholding villagers did not follow ideologies of men's and women's work very strictly, varying with demographic, ecological and economic conditions. Villagers said, for example, that hoeing the rice fields, and tapping rubber was men's work and planting was women's work, yet mixed sex groups could be observed in most activities. Here, in the 1970s and 1980s, it could be suggested that the supposedly fixed sexual division of labour was breaking down under the strains of a declining village economy heading into oblivion as industrialization and out-migration grew apace (Stivens, 1996). However, it is also possible that practices were always more flexible than ideology suggested.

\section{Methods}

\section{Population and sample size}

The latest population census in Nigeria is the 2006 population census. The researcher worked with the 2006 census, which gave Nrobo a total population of 7,715, with a population projection of 9,715 in 2016 (National Population Commission, 2007). Samples for qualitative studies are generally much smaller than those used in quantitative studies. Ritchie et al. (2003) provide reasons for this. There is a point of diminishing returns to a qualitative sample, that is, as the study goes on, more data does not necessarily lead to more information (Glaser and Strauss, 1967). This is when the collection of new data does not shed any further light on the issue under investigation. Researchers in qualitative studies use saturation as a guiding principle during their data collection. In a study to determine how many interviews that are needed to identify metathemes in multisited and cross-cultural research, Hagaman and Wutich (2017) found that 16 or fewer interviews were enough to identify common themes from sites with relatively homogeneous groups. A total of 23 semistructured interviews were conducted. The major questions asked were the following. What are the subsistence strategies of the Nrobo? What are the gendered role patterns of economic relations of the Nrobo? What are the gendered gaps in economic relations of the Nrobo?
Gender and rural economic relations 
JHASS 4,3

Focus group discussion (FGD), sample size was 18. The sample was gender-balanced. That was, nine women and nine men constituted the sample. The sample was drawn purposively from men and women, for 70 years and above. The participants were enlisted through personal contacts. The criteria for enlisting the participant were based on age, gender and consistency in the community.

\section{2}

\section{Participant observation}

My fieldwork among the Nrobo began with a pilot study that began in June 2015. This lasted for two months, that is, from 20 June 2015 to 22 August 2015. However, I fully settled in the Community on 5 September 2015. My fieldwork was planned in a way that enabled me to leave for the field every Wednesday and return every Monday morning to continue with my duties at Paul University, where I work. My fieldwork ended on 25 August 2016.

The researcher engaged participant observation as the main instrument of data collection in this study. Participant observation is an important tool in ethnography (Okpoko and Ezeh, 2011). Babbie (2005) equated participant observation to field research and discussed four different positions on a continuum of roles that field researchers may play in this regard: complete participant, participant-as-observer, observer-as-participant and complete observer. Because of ethical and scientific considerations (Ugwu, 2017), the researcher used participant-as-observer variant of participant observation in this study. Here, the research intention was disclosed to the participants and members of the society.

Various participant observation strategies, including conversations on a selected topic, daily chitchat, which helps maintain rapport, and provides knowledge about what is going on, and prolonged interviews, that were unstructured were used. Also, Ember et al. (2007) state that the essential part of the participant-observation process is finding some knowledgeable persons that are willing to work with the ethnographer, to help interpret what the ethnographer observes and tell him/her about aspects of the culture that he/she may not have chance to see or may not be entitled to see. These types of people are known as informants. Fortunately, formal methods have been developed to help select the most knowledgeable informants. One such method is called the "cultural consensus model," which relies on the principle that those things that most informants agree on are probably cultural.

My research assistant was from the community. He was appropriate for the task because he had finished his ordinary national diploma program at one of the high institutions at Enugu. Therefore, with that level of education and proper guidance on what I needed; he was very enterprising. Also, with the help of my research assistant, informants knowledgeable in the area of data I was collecting, were selected. A set of questions ranging from gender roles in the family to economic activities were asked to a selected number of elderly women and men. This was done to understand what is cultural among the group, using cultural consensus models (Ember et al., 2007; Bernard, 2006). Using this procedure, two persons were selected, a man and a woman. The male informant is 84 years old, while the female informant is 81 years old. I did that to ensure that the informants were genderbalanced. These persons were regularly visited for more insights on data generated through chitchat and related observation.

During my fieldwork, I tried hard to live in the present with all events of interest to the research. Social events such as funerals, marriage ceremonies, market, and so on, were well attended. In some cases, I hunted with some hunters, went to the farm with my host family and helped during harvests. Regularly, I attended market (as it is the theatre of social and economic activities), which is conducted every four days of the week. 
The researcher used FGD, as a supplementary method to triangulate the data collected during the study. Okpoko and Ezeh (2011) state that there was no agreed number of participants or FGD sessions but all depended on the funding and research objectives. Following that, the researcher conducted three group sessions of six participants each. The participants are those who have attained the age of 60 years and above. The first group was made up of three men and three women. The second group was made up of six men and the third group, six women. That choice was made because of funding and staffing. Besides, there was an FGD guide, structured in themes. However, open-ended questions were used to solicit information from the study participants during the sessions.

Conducting a FGD was a big challenge. The first attempt to conduct the FGD was unsuccessful because the participants were absent. We were supposed to meet on a Sunday evening, 3.00 p.m. We waited but at a stage, my assistant suggested that we check on them to know why they were unable to come, even when we took time to remind them the previous day, and as such, all agreed that Sunday was a better day. Finally, we could only get one of them who told us that she was not feeling fine. I sympathized with her and I pleaded for another opportunity. When we got back to the venue, the father of my research assistant, who was supposed to be one of the participants, was there. The venue was right behind his house. He asked me how I thought that the plan would work when I had not specified to them what they stood to get for offering their time. I explained to him how it was not proper to promise them of anything, as that would influence their participation. However, he insisted that if I wanted to achieve results, there was the need to make provisions for time compensation even in the form of refreshment. I agreed with him to make provisions for refreshment after the FGD session.

He asked me about the identities of those I had invited, and I told him. He told me that he could not get to them immediately but promised to invite them the next Saturday, by 4:00 p.m. and that if I wanted, he would facilitate the two other sessions on Sunday between 12:00 and 4:00 p.m. That seemed a perfect arrangement to me and I accepted the plan.

I returned to Awka on Monday morning to make other arrangements that would permit my absence from my work. On Wednesday, I went back to start the preparation. I met the man and he assured me he would not fail.

On Saturday, around 3:30, I was there with my research assistant fully prepared for the session. Finally, we started by 4:15 p.m. When the session was going on, I found out that women were not vocal. They were not as free as the men in responding to the questions. I later contacted one of the women who told me that I should have arranged their own separately. I related that to the father of my research assistant who told me that it was normal but could not explain why. However, he assured me that the Sunday sessions would be arranged separately. We finished with refreshments and I thanked them for their time, and they pledged their support any time.

On Sunday, we were ready by 11:40 a.m. First session started by 12:08 p.m., with the men. The second session started by $3: 15$ p.m., with the women. All went successfully at last. In addition, refreshment followed each session.

\section{Analysis}

Data analysis began with the collection of data. Daily field experiences are recorded, sorted for meaning and the researcher coded and grouped the data obtained after each fieldwork to prepare for further field activities. The coding is descriptive, as it suits ethnographic research (Saldaña, 2013). Summarily, analysis of data obtained from participant observation started with deducting excerpts from field notes and tapes, categorization of excerpts into 
JHASS

4,3

204

common and uncommon facts. Next is sorting and analysis of facts based on different objectives of the research and writing up the report.

To examine the validity and reliability of the research findings, and of the researcher's interpretation of them, the researcher consulted those who participated in the research. The cultural consultants acted as judges, evaluating the findings of the study. Furthermore, FGD sessions were conducted at the end of the data collection to help cross-check the validity and reliability of the data collected from other instruments.

Because the focus group sessions were conducted via mixed languages, and data were transcribed and translated to English. Codes were given to the translations based on similarities and differences. The reports were organized under themes, reflecting the objectives of the study. I compared and contrasted one group session with another, in terms of gender category, and finally aligning the result with that obtained from other instruments.

The report is conducted in a way that allows weaving of the data obtained from all instruments into the narrative. Nevertheless, where a detailed quotation is done, the source is always disclosed.

\section{Findings}

The findings of this study as presented below are reflections from my participant observation among the society. The narrative is presented in a descriptive manner reflecting lived experiences.

\section{Farming}

Farming is the prestige occupation for both men and women. In agricultural production, men grow $\ddot{j}$ (yams) in varying species, prevalent of which are Dioscorea rotundata and Dioscorea alata, and okpa, Vigna subterranean (earthpea). Yam is seen as a prestige crop among the Nrobo. Yams are associated with various supernatural sanctions; they are symbols of human fertility, and they represent wealth in ceremonial activities. Nrobo women grow ogodo (manioc), but nkasi, Colocasia esculenta (cocoyams, taro), azizi, Zea mays (maize) are grown by both men and women, and "small crops": gourds, groundnuts, squash, beans and various leaf crops, are grown by women. However, livestock farming is not a gendered work.

Farming has been identified as one of the predominant economic activities among Nrobo women. The four days of the Igbo week alternate between farm and market days, and almost all women both farm and buy and sell in the market. There is a considerable range of variation in both the scale of farming and the extent of market trade. Both depend on the amount of farmland available to a woman and on individual factors such as physical strength, skill in farming and trade, personal ambition and childbirth. Her rights to the use of farmland are obtained through her husband, since her crops, with the exception of cassava, are grown on the edges of, and between the mounds, in which her husband's yams are planted. Cassava is either planted in yam heaps after the yams are harvested or grown in separate plots devoted to that crop alone. The amount of farmland a woman may use during a given season is largely a function of her husband's standing in relation to landholding groups with which he is associated and his personal initiative in dealing with them. A woman may farm more land than has been assigned to her by her husband if she can afford to rent it. Some husbands rent land for their wives' cassava crops, but they are not under obligation to do so.

The palm products processing is of minor importance, in contrast to many Igbo communities to the south and west. Men tapped palm-wine, while women processed palm 
oil. However, those women whose husbands are in the position of onyishi umumna (clan heads), are always advantaged in palm oil processing since all the palm trees under the husband's control are taken care of by the wife. In the words of a widow, whose husband had been clan head before his death:

When my husband was alive, he was the head of the clan and was in charge of the clan land. I was in control of all the palm trees on the land. All the palm oil I take to the market and the one we use for cooking come from it. However, since my husband died all have changed. Another person has taken over (female, 82 years).

In addition, women pick and process among the Igbo. Some married women who are not from Nrobo refer to this as ibe ohoyi.

\section{Fishing and hunting}

Fishing and hunting are important sources of income among few men of the villages. There are categories of hunters ranging from those who use local guns to those who use oppaa, a wooden stick with pointed sharp iron at one end of the stick and ordinary stick. Hunting is done in groups and they go as long as the boundary between Enugu State and Kogi State. The hunted animals either are used for family feeding or are sold to women who cut in sizes and cook them for resale. It is ironic to say that hunters sell to the women and still buy the same from them.

In the case of fishing, the Nrobo has no river of its own. However, the men also go as far as Abbi to fish in the river marking the boundary between Enugu State and Kogi State. This River, Eshị Avưuge, belongs to Kogi State. However, fishing is always done in the rainy season when the water level is high. Below is a reflection from one of the participant's accounts.

We fish in the rainy season. We go as long as Eshi Avuruge, which belongs to Kogi. We go in groups all the time to avoid unforeseen challenges. Some who know how to fish, others will hunt for bush animals. But hunting is profitable during the dry season (male, 34 years) (Plate 1).

\section{Trading}

Both men and women conduct local trade in markets in or near Nrobo. Men sell yams, meat and various kinds of diffused goods; women sell their surplus farm crops, clay pots of their own manufacture, fresh and dried fish, poultry and eggs, salt, rice, cooked foods and sometimes other goods such as kerosene or soap. Long-distance trade in fish and yams from the Nrobo area and other cities of eastern Nigeria is the exclusive province of men. Nrobo women are discouraged from engaging in this trade, except in pots, and the few who have
Gender and rural economic relations

205

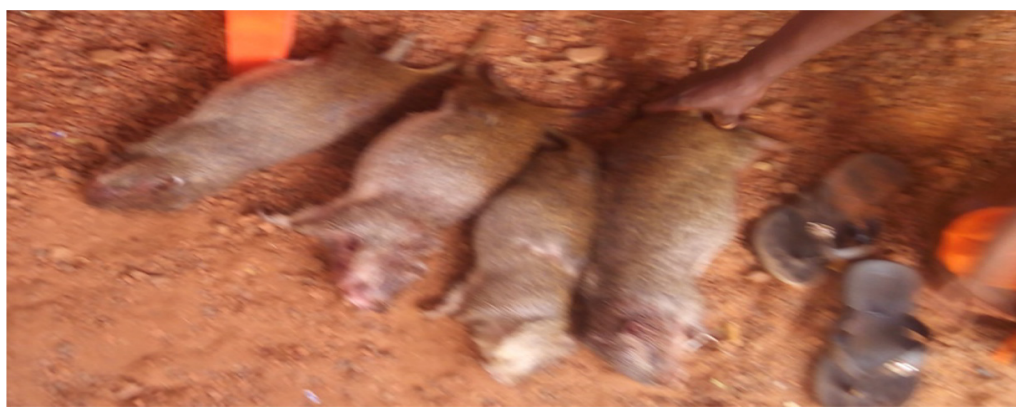

Plate 1.

Some cane rats hunted by Nrobo men 


\section{JHASS 4,3}

206
Plate 2.

Preparation for longdistance trade in pot, processed cassava and other items attempted it have stopped after a short time. This seems to be associated with women's lack of wealth for trading capital, the restrictions placed on their mobility by their household economic responsibilities and controls exerted over them by the men of Nrobo.

Since it is not customary for a man to give his wife money with which to start trade, a woman usually begins trading with a slender margin of her agricultural surplus, and perhaps from clay pots she has made. Savings from the sale of agricultural surplus helps her to acquire sufficient trading capital to buy goods wholesale that are resold in retails. Before now, it is generally only the older women, largely freed from the duties of childbearing and child caring that are able to trade outside the Nrobo. Nevertheless, trade is of great importance in the eyes of Nrobo women. Not only does it represent a means of acquiring economic independence and possibly wealth, both of which are highly valued by the Nrobo but also because a market day is a welcome break from the toll and monotony of farming and household tasks (Plate 2).

Before and presently many Nrobo women do not see themselves as full-time traders, able and ambitious women may increase their market profits by taking advantage of price differentials within the local market network. One central market known as Orie, which is conducted every four days, serves all the Nrobo villages, while several people sell within the comfort of their house all the other days of the week. In addition, there are numbers of central markets within neighbouring communities and other smaller markets within a radius of ten or fifteen miles of Nrobo. In certain of the outlying ones, products such as yams, cassava and clay pots cost more than in Nrobo, where prices tend to be slightly lower. In addition, this gives the Nrobo women the advantage of making profit.

Certain products, either grown on farms or purchased in a market, are processed for sale by Nrobo women. These include prepared foods, the most important of which are gari or $a r i b$ o (cassava meal), ọpape (peanuts) grown or bought in bulk and roasted, rice bought wholesale in an area where it is plentiful and then sold locally and tobacco bought in "ropes" and ground into snuff. In both these types of trade, profit is obtained at the expense of considerable exertion: carrying loads long distances, processing the materials to be sold or both.

Another method of making profit from market sales is the purchase of goods in quantity for resale in small amounts. Akpọko, (chili peppers) Capsicum annuum, egushi, (calabash seeds) Lagenaria siceraria, ịshe (dried crayfish) and iyịriy $a z u$ (small pieces of dried fish used in soup), are bought in large quantity and resold by the English cigarette tinful - a fairly standard measure for Nigerian markets - or by the measure of the lid of the cigarette tin, as in the case of iyiriy $a z u$ Such trade requires a greater initial outlay and is thus closed to women who do not have the resources to buy goods in quantity. Some women may be helped to undertake this type of trade by a husband or a male relative who is a professional trader, or several women may pool their resources to buy a sack of crayfish or iced fish.

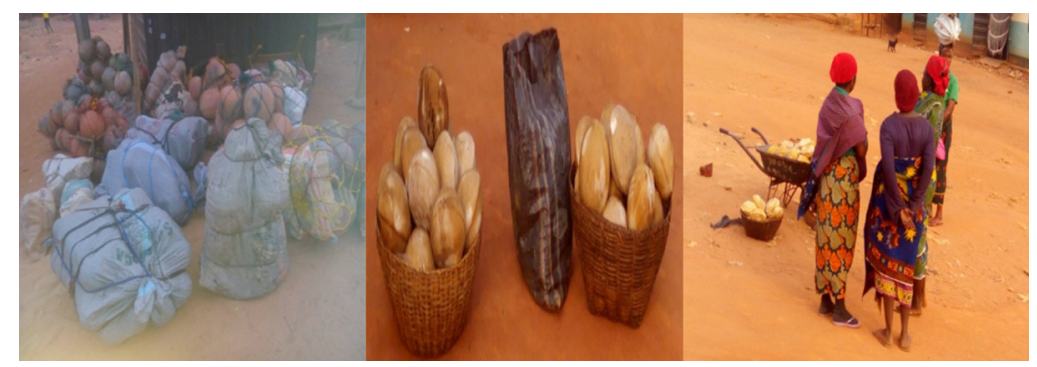


As in the case of farming, the factors of physical strength and personal ambition are important to a female trader's success. Since the only practical means of travel between Nrobo and most of the neighbouring markets are on foot and since goods are transported in head loads, both these qualities are necessary to success. Though most Nrobo are accustomed to walking distances up to 15 miles or more in a day, they live in hilly country, and some of the terrain is rugged, particularly that between Nrobo and Edem, Abbi or Ibagwa Nkwọ, which seem to offer some of the better trading opportunities. Though opportunities for the acquisition of wealth are available, there is no shortcut to success.

Success or failure of market trade may depend on other factors. One is the trader's choice of commodity and the markets at which she will buy and sell. Though the prevailing prices of the different goods in the various markets within walking distance of Nrobo are well known, an alert trader may take advantage of seasonal variations. For example, during the dry season when oranges are scarce, they sell for higher prices at surrounding markets, while at Nrobo they sell at lower prices. Another factor is the effectiveness of a trader's salesmanship and of her interpersonal relations in general. Since many people may be selling the same commodity in the same market at the same time and at the same price, personal ties such as friendship and membership in the same kinship, residence or association group may also be important in a buyer's choice of which seller to patronize.

The Nrobo do not seem to have any other well-developed system of holding food products against periods of scarcity, except the clay pots and the barns. There is little doubt that women traders understand the advantages of such a practice, but they emphasize quick turnover of commodities bought and sold.

However, many Nrobo women sell cassava meal, clay pot, and so on, at Nkwọ Ibagwa, Eke Abbi and Ahọ Edem, where the market for it is better than in Nrobo during the famine period. Nkwọ Ibagwa is a market situated at Ibagwa-Eka community, in Igbo-Eze South Local Government Area and Ahọ Edem is a market in Edem community, in Nsukka Local Government Area, while Eke Abbị is a market in Abbị community in Uzọ-Uwanị Local Government Area, all in Enugu state. All of these markets hold according to the Igbo market name given after them. For example, Nkwọ Ibagwa holds on nkwo day, and so on. These markets are important because they are more open to contact than Orie Nrobo. One woman maintained that she went to Eke Abbi each market day during this period because she was "hard up and must earn food money then" - "m nwọny ne-eje n eke Abbị ashua n"ile maka mkpa ego ne nri." (I go to Eke Abbi every market day because of the need for money and food). Though this may seem uneconomic, there are several reasons for it. First, the season at which the highest prices are obtainable for staple foods is also the season of greatest farming activities. Since frequent weeding of crops is necessary, and a woman must cultivate her own crops and also weed her husband's yams, the burden of heavy farm work, plus the necessity of walking as much as six or seven miles each way between village and farm, precludes active participation in market trade. Second, the rains make the road path between Nrobo and other neighbouring communities very difficult during this time.

Crafts

Clay pot making is the third major economic activity of Nrobo women. Although the women are seen to be specialists in clay pot making, the clay used in making the pots is dug out by the men. The clay is bought in bags with prices ranging from $\$ 200$ to $\$ 500$ per bag (Plate 3).

Before now, Nrobo women did not learn to make clay pots until they marry, but thereafter the majority time is spent in making pots during the dry season, when farming duties are relatively light. Motivation is almost wholly economic. One elderly woman, when
Gender and rural economic relations

207 
JHASS
4,3

208

\section{Plate 3.}

Researcher with claydigger and women who are buying clay at Umuoyo hill

\section{Plate 4.}

Researcher with a pot-maker: photo by Geoffrey Ugwu asked why she made clay pots, replied, "So I will not die of hunger." Another explained, "Hunger forces me to do so." However, some younger women do not make clay pots, giving various reasons for this: having lived away from Nrobo during the time when they would ordinarily have learned to make them, failure in their attempts to learn pottery techniques, or the feeling that they can earn more from other activities.

Besides the few clay pots that they keep for household use, women usually sell their best clay pots wholesale to long-distance traders. Some women sell their clay pots as soon as they are made, while others save some as a reserve fund for emergencies (Plate 4).

Blacksmithing, mortar making and mask making are exclusive crafts for men. Blacksmithing and mortar making are hard jobs that demand more physical strength for success. As a result, few men are in these crafts. For instance, throughout my stay in the community I was able to interact with only one blacksmith and one mortar maker. Apart from physical strength, both craft works require creative ability for success.

Mask making is also another exclusive craft for men. This might be because men controlled the supernatural sphere and masked spirits are said to be agents of the supernatural. Even though I was not able to witness any person performing this craft, I was told that it is a seasonal craft.

Nrobo women also embark on dressmaking and mending of clothes by machine and midwifery. Since a woman becomes a traditional birth attendant and herbalist, (medicine woman), only through a complex process of supernatural revelation, few women are thus employed. This occupation is more rewarding in prestige than in financial remuneration.

Medicine men (herbalists) are more pronounced in their pursuit of reward than women are. Like women, the men also become herbalists and diviners through a complex process of
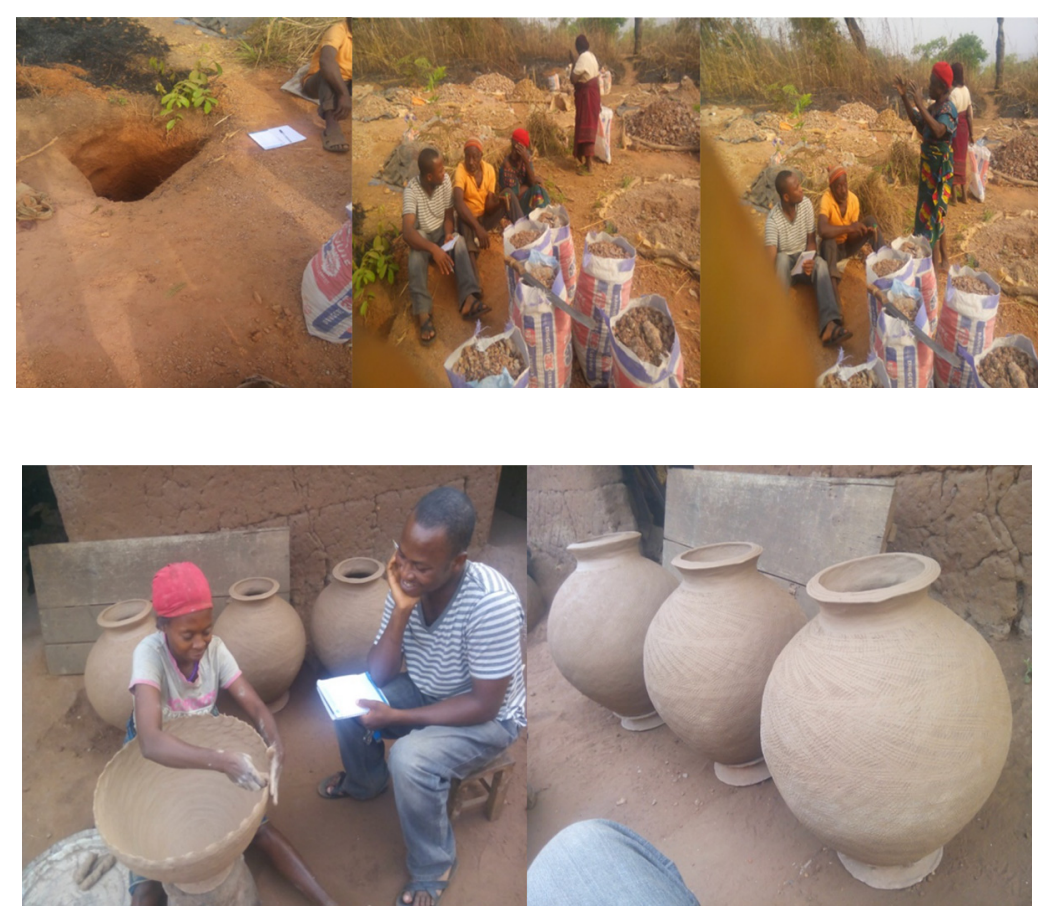
spiritual revelation. Although some men may like to learn this practice, many of them have been unsuccessful.

Basket making is said to be a craft that everyone can venture in, irrespective of gendered categories. However, my stay in the community confirmed only a few males, some of them very young, who are in this craft. As in the case of other crafts, creative ability is also very necessary for a person's success.

Gender roles in the family

The division of labour is chiefly by sex. Responsibility for the support of the household is divided between husband and wife. It is expected that women have the responsibility of child bearing and rearing. It is common to hear women and men say, "nwonyenye a nuguejezi $a z u$ [woman does not go far]," "he ne ehe ununtivi [they take care of children]." The husband is supposed to provide sufficient yams for the needs of his wife and children during the period when yams are plentiful, from September through January or February, and to give her meat or fish at the time of festivals. The wife is supposed to provide the staple root crops from approximately February to September and salt, palm oil, peppers, and other vegetable crops throughout the year.

Within the polygynous family, the division of labour is according to the component elementary families; economic cooperation between wives of the same husband is minimal. Not only do husband and wife farm their crops separately, but also each owns the crops he/ she produces. The wife's right to keep the profits from her own production and trade over and above her contribution to the maintenance of the household is of basic importance to the economic status of women generally. Though Nrobo says that a husband may demand that his wife give him her market profits, this seldom occurs.

\section{Discussion}

From the findings, a close look at the subsistence activities of the Nrobo shows that the society is still an agricultural economy. Although there are few skilled workers, they always take their farm work as primary. This compares with what Ottenberg (1970) found among the Afikpo and what Green (1964) found among the Umeke Agbaja. This means that the change is not as rapid as one would have anticipated using these ethnographies of other Igbo groups as bases for comparison for such a long period.

The traditional gender pattern of economic relation of the Nrobo follows an ideological pattern that permits the division of labour between men and women when compared with what Amadiume (1997) found among the Nnobi. This is rooted in the explanation that some works are more suited for women and others for men. However, when one looks at the situation on ground, it does not follow that ideology. This is because, from what were observed, both women and men partake in some activities deemed fit for either men or women. For example, women identified that it was their duty to take care of the children but men are left with this function whenever women are engaged in other tasks elsewhere. Furthermore, men have been associated with those tasks that demand more physical strength such as tilling of land for crop production. However, many times I have seen few women do this. This actually follows functionalists' explanations that the roles in society must be filled up for the efficient running of the society. When men are lacking in their ability to perform their roles, women see those roles fall on them and vice versa. While some do that to cover up for imminent shame, others do that as a matter of necessity.

Among the Nrobo, women perform more subsistence tasks and are not actually complaining about this. This also compares with what Green (1964) found among the Umeke Agbaja where men admitted that women even feed them. The times problems arise are when men who do not live up to their expectations, misbehave, especially when they get
Gender and rural economic relations 
JHASS 4,3

drunk with their wives' money. Even though women contribute greatly to subsistence economic activities, they are not flouting the authority of their husbands. This supports the explanation by cultural feminist, which extols the positive aspects of feminine personality. Margaret Fuller, Jane Adams, proponents of the theory, argued that in the governing of the state, society needed such women virtues as hardworking, cooperation, caring, pacifism and nonviolence in the settlement of conflicts (Ritzer and Stepnisky, 2014).

The task of identifying the gnosis, underlying gendered gap requires us to discursively, enter the landscape of Nrobo itself. We will begin with what most of the women always say. "Ke nwonyeke ahale ne nya tuaru nwonyenye [male child is valued more than the female child]." The Nrobo believe that no matter how small a male child is; he is rated above female. The ideal of the superiority of men over women is backed by men's controls over land and the supernatural. This is explicit in the words of many Nrobo women, "He le eri anyi [men control land]." "Me he bu nu whu oshekere ohe [men also are custodians of ohe deity]," "Nwonyenye a nunigi abuatama maa [women are not custodians of deities]".

However, when compared with Ohafia, land is controlled by matrilineal groups. Also, McCall (2000) has demonstrated ethnographically using the case of Nne Uko, an Ohafia woman whose gender was transformed following her masculine achievements, that roles are not gender-specific. Nne Uko had risen from her prowess in masculine activities and even married two wives. She had large bans of yam and was even admitted to ekpe society, thought to be exclusive to men. She became known in her community by dike nwami, a term that translates "warrior woman" among them. She also rose to the position of priestess of her matrilineage's $u d u d u$ shrine.

However, Nrobo men react differently. In their words, "ego o na-akọ nwonyenye akọ [does a woman lack money]?" "Me he nwe n meme ekwu wama ukpaa (ibe-ohoyi), woma orome [women process palm produce, Irvingia gabonensis and also pluck oranges]." "I cheru ne ego shii n'iye whuduja [do you think the money got from all these is small]?" "He nuwhuere ogodo [they also process and sell cassava].” Nrobo men see women as having many sources of income and believe that women do not lack money. One elderly man recounts that his wife was able to provide for the family during the famine period, from her savings.

According to Inglehart and Pippa (2003), an extensive literature in sociology and anthropology has documented the familiar yet profound transformation of sex roles associated with the process of societal modernization. One, virtually all preindustrial societies emphasize childbearing and child rearing as the central goal for women and their most important function in life, along with tasks such as food production and preparation at home; jobs in the paid workforce are predominantly male. In post-industrial societies, gender roles have increasingly converged because of a structural revolution in the paid labour force, in educational opportunities for women, and in the characteristics of modern families. Two, in most affluent countries, people are marrying later than in previous generations and having fewer children. Three a rapid increase in premarital cohabitation is challenging the onceprivileged position held by marriage. An increasing number of women, especially those who are married, have entered the paid labour force, creating the transition from male breadwinner to dual-earning families. Four, although the gender gap in rates of economic participation is narrowing, women and men roles in the labour force continue to differ. Women still have to juggle the demands of family responsibilities and market work, and they hold different jobs than men do, often with lower status and rewards. These social trends raise questions about long-established moral values and attitudes toward the family and gender roles that were once taken for granted. Traditional family values have by no means disappeared, but they appear to be under greater strain in modern societies (Hann and Hart, 2011). 


\section{Theoretical analysis}

Initially, what I projected to be used, as theoretical frameworks for this study were functionalism as propounded by Malinowski (1944), and gender inequality theory as propounded by Friedan (1963), from feminist perspectives. Even though I had a theoretical sense of what I was setting out to investigate, it was impossible to determine the nature of the result before actually going to the field. These two were chosen because of their general applicability to the topic that I set out to study. However, data from Nrobo shows that cultural feminism as propounded by Margaret Fuller, Jane Adams to mention only these, who argued that in the governing of the state, society needed such women's virtues as cooperation, caring and pacifism (Ritzer and Stepnisky, 2014), is to be added at this stage.

In summary, functionalism sees gender relations in terms of function, which each gender category performs for the overall survival and maintenance of society. Based on this, there is a need to divide these functions appropriately. The best way is the division of labour between the male and female. Both male and female contribute to the overall functioning and maintenance of the Nrobo. That is, if $\mathrm{M}$ is male and performs role $\mathrm{a} 1, \mathrm{a} 2$, and $\mathrm{F}$ is female and performs role $\mathrm{b} 1, \mathrm{~b} 2$, both $\mathrm{a} 1+\mathrm{a} 2$ and $\mathrm{b} 1+\mathrm{b} 2$ are seen as a complement of $\mathrm{c}$, which represents Nrobo. Hence, $[(\mathrm{a} 1+\mathrm{a} 2)+(\mathrm{b} 1+\mathrm{b} 2)=\mathrm{c}]$ (Figure 1$)$.

However, these roles, in the case of $\mathrm{a} 2$ and $\mathrm{b} 2$ are not gender constant in some cases. This division of roles is needed, to keep the Nrobo going. The functions of each gender category are needed to keep the society.

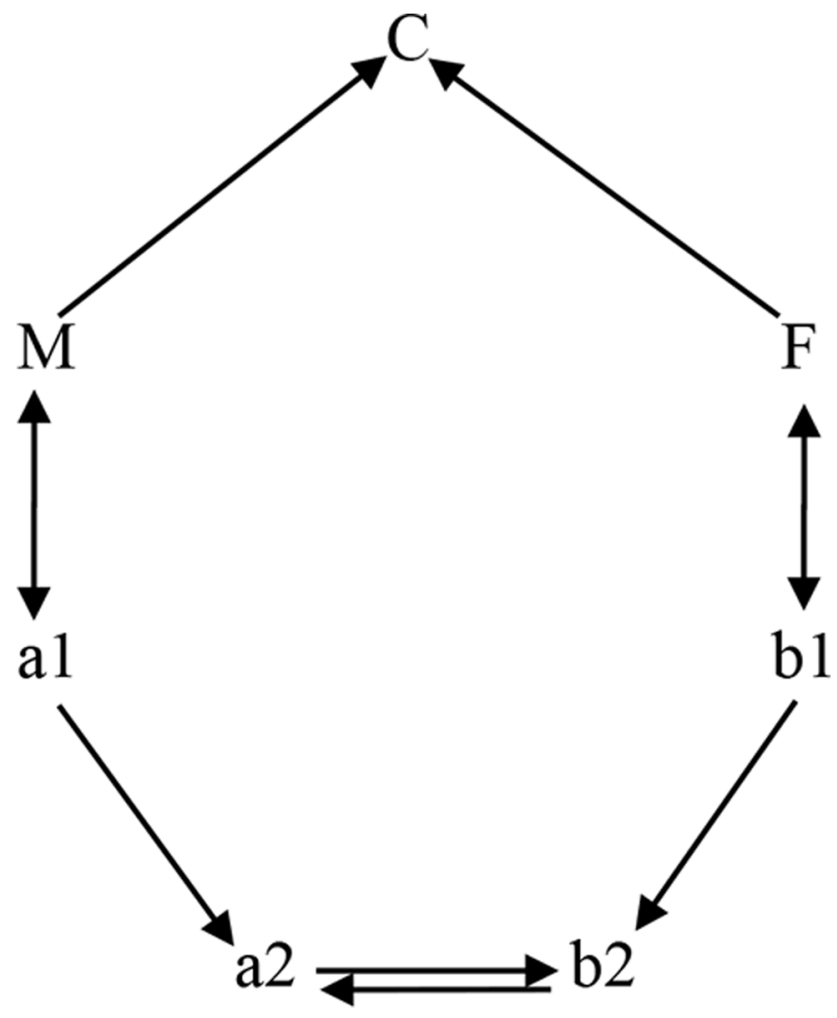

Gender and rural economic relations 
JHASS

4,3

212

From the feminist theories reviewed, the theory of gender inequality is adopted as one of the theoretical frameworks of this study. Four themes characterize feminist theorizing of gender inequality. Men and women are situated in society not only differently but also unequally. Women get less of the material resources, social status, power and opportunities for selfactualization than do men who share their social location - be it a location based on class, race, occupation, ethnicity, religion, education, nationality or any intersection of these factors. This inequality results from the organization of society, for although individual human beings vary in their profile of potentials and traits, no significant pattern of natural variation distinguishes the sexes. All human beings are characterized by an intrinsic need for self-actualization and by a fundamental malleability that lets them adapt to the constraints or opportunities of their situations. To say that there is gender inequality is to claim that women are situationally less empowered than men are to realize the need they share with men for self-actualization. All inequality theorists assume that both women and men will respond easily to more egalitarian social structures and situations.

The ethnographic evidence on Nrobo refutes some of these assumptions. For example, both men and women of Nrobo have differing views of who actually control resources. Accepting that men do own land, most of the agricultural input on the land is controlled by women. The assumption of women getting less because of how the society is organized is not proven here. The evidence of this study supports the explanation by cultural feminist, which extols the positive aspects of feminine personality.

\section{Practical and policy implication}

Practically, the finding of ethnography of this kind is beneficial to every facet of society. This study exposes the structure of gender and economic relations of the Nrobo. As such, the government, research and development institutes, NGOs and policy makers can acquire insight that may assist in the formulation of policies that would improve the Nrobo.

\section{Conclusion}

Although the Nrobo society has witnessed acculturation, economic relations still reflect the traditional structure. Even though there are still verbal expressions of gendered roles division, it does not mirror what actually obtains in society, except bio-social roles. Ideological superiority of men reflects the patrilineal kinship arrangement of the society.

Theoretically, some of the hypotheses of gender inequality (socialist) theory were disputed because they could not adequately explain gender and economic relations in an egalitarian-reflected society such as Nrobo. It therefore recommended that further research in this area should be holistic to reflect/capture the interstices between kinship, political, religious and gendered relations.

\section{References}

Agbasiere, J. (2001), Women in Igbo Life and Thought, Routledge, London.

Amadiume, I. (1997), Re-Inventing Africa Matriarchy, Religion and Culture, Zed Books Ltd., New York, NY.

Babbie, E. (2005), The Basics of Social Research, Wadsworth, CA.

Baden, S. and Goetz, A.M. (1998), "Who needs [sex] when you can have [gender]? Conflicting discourses on gender at Beijing", in Jackson, C. and Pearson, R. (Eds), Feminist Visions of Development: gender Analysis and Policy, Routledge, London.

Benería, L. (1982), Women and Development: The Sexual Division of Labor in Rural Societies, Praeger, New York, NY. 
Bernard, R.H. (2006), Research Methods in Anthropology: Qualitative and Quantitative Approches, AltaMira Press, Oxford.

Boserup, E. (1989), Woman's Role in Economic Development, Earthscan, London.

Cook, N. (2007), Gender Relation in Global Perspective: Essential Readings, Canadian Scholars' Press, Inc., Toronto, Ontario.

Edholm, F., Harris, O. and Young, K. (1977), “Conceptualising women”, Critique of Anthropology, Vol. 3 Nos 9/10, pp. 101-130.

Ember, C.R., Ember, M. and Peregrine, P.N. (2007), Anthropology. Upper Saddle River, Pearson Education LTD, NJ.

Equiano, O. (1988), The Astonishing Story of the Life of Olaudah Equiano, or Gustavus Vassa the African; Written by Himself, ABIC Books, Enugu.

Friedan, B. (1963), The Feminine Mystique, Dell, New York, NY.

Glaser, B. and Strauss, A. (1967), The Discovery of Grounded Theory: Strategies for Qualitative Research, Aldine Publishing Company, New York, NY.

Goody, J. (1976), Production and Reproduction: A Comparative Study of the Domestic Domain, Cambridge University Press, Cambridge.

Green, M.M. (1964), The Ibo Village Affairs, Frederick A Praeger, Inc., New York, NY.

Hagaman, A.K. and Wutich, A. (2017), "How many interviews are enough to identify metathemes in multicited and cross-cultural research? Another perspective on guest, Bunce and Johnson's (2006) landmark study", Field Methods, Vol. 29 No. 1, pp. 23-41.

Hann, C. and Hart, K. (2011), Economic Anthropology: History, Ethnography, Critique, Polity Press, Cambridge.

Harris, O. (1984), "Households as natural units", in Young, K., Wolkowitz, C. and McCullagh, R. (Eds), Of Marriage and the Market, Routledge and Kegan Paul, London.

Harris, O. and Young, K. (1981), "Engendered structures: some problems in the analysis of reproduction", The Anthropology of Pre-Capitalist Societies, Macmillan, London.

Hill, K. and Hurtado, A.M. (1996), "The evolution of premature reproductive senescence and menopause in human females: an evaluation of the grandmother hypothesis", in Betzig, L. (Ed.), Human Nature: A Critical Reader, Oxford University Press, New York, NY.

Inglehart, R. and Pippa, N. (2003), Rising Tide: Gender Equality and Cultural Change around the World, Cambridge University Press, New York, NY.

Lamphere, L. (2007), "The domestic sphere of women and the public world of men: the strengths and limitations of an anthropological dichotomy", in Cook, N. (Ed.), Gender Relation in Global Perspective: Essential Readings, Canadian Scholars' Press, Inc., Toronto, Ontario, pp. 7-16.

Lee, R.B. (2013), The Dobe Ju/'hoansi, 4th ed., Cengage Learning, Wadsworth.

Lee, R.B. and DeVore, I. (Eds) (1968), Man the Hunter, Aldine, Chicago.

Leith-Ross, S. (1965), African Woman, Praeger, New York, NY.

McCall, J.C. (2000), Dancing Histories: Heuristic Ethnography with the Ohafia Igbo, The University of MI Press, MI.

Malinowski, B. (1944), A Scientific Theory of Culture and Other Essays, University of NC Press, Chapel Hill.

Meillassoux, C. (1981), Maidens, Meal and Money: Capitalism and the Domestic Community, Cambridge University Press, Cambridge.

Moore, H. (1988), Feminism and Anthropology, Polity, Cambridge.

Narotzky, S. (1997), New Directions in Economic Anthropology, Pluto, London.

National Population Commission (2007), "Nigeria population census of 2006", available at: http:// population.gov.ng 
JHASS

4,3

Nsugbe, P.O. (1974), Ohaffia - a Matrilineal Ibo People, The Clarender Press, Oxford.

Okpoko, P. and Ezeh, P.-J. (2011), Methods in Qualitative Research, Great Ap Express Publishers Limited, Nsukka.

Ottenberg, P.V. (1970), "The changing economic position of women among the Afikpo Ibo", in Bascom, W.R. and Herskovit, M.J. (Eds), Continuity and Change in African Cultures, The University of Chicago Press, Chicago and London.

Ritchie, J., Lewis, J. and Elam, G. (2003), "Designing and selecting samples”, in Ritchie, J. and Lewis, J. (Eds), Qualitative Research Practice: A Guide for Social Science Students and Researchers, Sage, Thousand Oaks, CA, pp. 77-108.

Ritzer, G. and Stepnisky, J. (2014), Sociological Theory, McGraw-Hill, New York, NY.

Sahlins, M. (1972), Stone Age Economics, Aldine, Chicago.

Saldaña, J. (2013), The Coding Manual for Qualitative Researchers, SAGE Publications Ltd., London.

Stivens, M. (1996), Matriliny and Modernity: sexual Politics and Social Change in Rural Malaysia, Allen and Unwin, St Leonards, NSW.

Ugwu, U.T. (2017), "Compromised or not: the challenges of ethics in qualitative research", Nigerian Journal of Social Sciences, Vol. 13 No. 2, pp. 159-166.

United Nations Development Programme (2018), Human Development Indices and Indicators: 2018 Statistical Update, United Nations Development Programme, New York, NY.

\section{Further reading}

Malinowski, B. (1922), Argonauts of the Western Pacific: An account of Native Enterprise and Adventure in the Archipelagoes of Melanesian New Guinea, Routledge and Kegan Paul Ltd., London.

Schutz, E.A., Lavenda, R.H. and Dods, R.R. (2009), Cultural Anthropology: A Perspective on the Human Condition, Canadian ed., Oxford University Press, Canada.

\section{Corresponding author}

Ugochukwu Titus Ugwu can be contacted at: ut.ugwu@unizik.edu.ng

For instructions on how to order reprints of this article, please visit our website: 